\title{
?Amphictis (Carnivora, Ailuridae) from the Belgrade Formation of North Carolina, USA
}

\author{
Jon Baskin ${ }^{\text {Corresp., } 1,2}$, Edwin Dickinson ${ }^{3}$, John DuBois ${ }^{4}$, Henry Galiano ${ }^{5}$, Adam Hartstone-Rose ${ }^{3}$ \\ ${ }^{1}$ Department of Biological and Health Sciences, Texas A\&M University - Kingsville, Kingsville, Texas, United States of America \\ UT Jackson School of Geoscience, University of Texas at Austin, Austin, Texas, United States of America \\ 3 Department of Biological Sciences, North Carolina State University, Raleigh, North Carolina, United States of America \\ 4 Unaffiliated, Benson, North Carolina, United States of America \\ 5 Maxilla \& Mandible, Ltd., New York, New York, United States of America \\ Corresponding Author: Jon Baskin \\ Email address: jon.baskin@tamuk.edu
}

Miocene terrestrial mammals are poorly known from the Atlantic Coastal Plain. Fossils of the Order Carnivora from this time and region are especially rare. We describe a carnivoran mandible with a p4 from the late Oligocene or early early Miocene Belgrade Formation in Onslow County, North Carolina. Comparisons are made with carnivoran jaws with similar premolar and molar lengths from the late Oligocene and Miocene of North America and Eurasia. These indicate that the North Carolina jaw is assignable to the Ailuridae, a family whose only living member is the red panda. The jaw is tentatively referred to Amphictis, a genus known elsewhere from the late Oligocene and early Miocene of Europe and the early Miocene (Hemingfordian) of North America.

The North Carolina mandible compares best with the late Oligocene (MP 28) Amphictis ambiguus from Pech du Fraysse, France, the oldest known member of the Family Ailuridae, and with the early Miocene (MN 1-MN 2a) A. schlosseri from southwestern Germany. This identification is compatible with a late late Arikareean (Ar4, early Miocene, MN 2-3 equivalent) age assignment for the other terrestrial mammals of the Belgrade Formation. 


\section{1 ?Amphictis (Carnivora, Ailuridae) from the Belgrade}

\section{Formation of North Carolina, USA}

3 Jon A. Baskin ${ }^{1,2}$, Edwin Dickinson ${ }^{3}$, John DuBois ${ }^{4}$, Henry Galiano ${ }^{5}$, Adam Hartstone-Rose ${ }^{3}$

4

$5{ }^{1}$ Department of Biological and Health Sciences, Texas A\&M University-Kingsville, Kingsville,

6 Texas, United States of America

7 2Research Associate, UT Jackson School of Geoscience, University of Texas at Austin, Austin,

8 Texas, United States of America

$9{ }^{3}$ Department of Biological Sciences, North Carolina State University, Raleigh, North Carolina, 10 United States of America

$11{ }^{4} 385$ Camelia Road, Benson, North Carolina, USA

$12{ }^{5}$ Maxilla \& Mandible, Ltd., 459 Columbus Avenue, Ste 117, New York, New York, United

13 States of America

14

15 Corresponding Author:

16 Jon Baskin ${ }^{1}$

17 Department of Biological and Health Sciences, Texas A\&M University-Kingsville, Kingsville, 18 Texas, 78363, United States of America Email address:Jon.Baskin@tamuk.edu 
20

21

22

23

24

25

26

27

28

29

30

31

32

33

34

35

36

37

38

39

40

41

42

43

44

45

46

47

48

49

50

51

52

53

54

55

56

57

58

59

60

61

62

\section{Abstract}

Miocene terrestrial mammals are poorly known from the Atlantic Coastal Plain. Fossils of the Order Carnivora from this time and region are especially rare. We describe a carnivoran mandible with a 4 from the late Oligocene or early early Miocene Belgrade Formation in Onslow County, North Carolina. Comparisons are made with carnivoran jaws with similar premolar and molar lengths from the late Oligocene and Miocene of North America and Eurasia. These indicate that the North Carolina jaw is assignable to the Ailuridae, a family whose only living member is the red panda. The jaw is tentatively referred to Amphictis, a genus known elsewhere from the late Oligocene and early Miocene of Europe and the early Miocene (Hemingfordian) of North America.

The North Carolina mandible compares best with the late Oligocene (MP 28) Amphictis ambigua from Pech du Fraysse, France, the oldest known member of the Family Ailuridae, and with the early Miocene (MN 1-MN 2a) A. schlosseri from southwestern Germany. This identification is compatible with a late late Arikareean (Ar4, early Miocene, MN 2-3 equivalent) age assignment for the other terrestrial mammals of the Belgrade Formation.

\section{Introduction}

Tertiary terrestrial mammals are known from a few localities on Atlantic Coastal Plain (Tedford et al., 2004). Only four of these contain terrestrial carnivorans. The Farmingdale Local Fauna of New Jersey, initially assigned to the early Hemingfordian (Tedford \& Hunter, 1984), is late late Arikareean (Ar4, MN 2-3 equivalent) in age (Emry \& Eshelman, 1998). An indeterminate canid is recorded from there (Gallagher et al., 1995). The early Hemingfordian (He1, MN 4 equivalent) Pollack Farm Local Fauna of Delaware is from the Calvert Formation. It contains at least 26 species of land mammals (Emry \& Eshelman, 1998). Carnivorans present are two procyonids, two borophagine canids, an ursid, and two amphicyonids. The Barstovian Chesapeake Bay Fauna of Maryland and Virginia is from the Calvert and overlying Choptank Formations (Wright \& Eshelman, 1987). Amphicyon and the borophagine canid ?Cynarctus marylandica are recorded in the fauna (Tedford et al., 2004). The Lee Creek Mine Local Fauna is from the Lower to Upper Pliocene Yorktown Formation in North Carolina (Snyder, Mauger \& Akers, 1983). Eshelman \& Whitmore (2008) documented 16 taxa from there, including two borophagine canids, an ursid, and a felid.

The Belgrade Quarry in Onslow County, North Carolina exposes strata of Oligocene through Pleistocene age (Locality 20 of Ward, Lawrence \& Blackwelder, 1978: fig 2; Locality 1 of Zulo, 1984). At the quarry, marine invertebrates and vertebrates have been recovered from the River Bend Formation and the overlying Belgrade Formation (e.g., Rossbach \& Carter, 1991; Boesseneker, Ahmed \& Geisler, 2017). The River Bend Formation is a shell hash limestone. The Belgrade Formation, which is divided into the lower Pollocksville and upper Haywood Landing Members, consists of marine shell beds, sands, and clay (Ward, Lawrence \& Blackwelder, 1978). 
63

64

65

66

67

68

69

70

71

72

73

74

75

76

77

78

79

80

81

82

83

84

85

86

87

88

89

90

91

92

93

94

95

96

97

98

99

100

101

102

103

104

105

106

107

The carnivoran jaw (NCSM 33670) described below is likely from the Belgrade Formation. At the quarry, the middle to late Oligocene River Bend Formation is mined for aggregate (McCleod \& Barnes, 2008). Belgrade Formation sediments are bulldozed off of it and placed into small piles that are exposed to the elements. A mammal jaw with a p4 (NCSM 33670) was recovered while surface collecting for shark teeth and other fossils after a heavy rainstorm. Ray dental plates and shark teeth from these spoil piles include Aetobatis sp., Dasyatis sp., Myliobatis sp., Rhinoptera sp., Galeocerdo sp., Hemipristis serra, Carcharhinus sp., Carcharodon angustidens, Carcharias sp., Nebrius sp., Isurus sp., and Physogaleus sp.

The age of the Belgrade Formation is disputed. It has been assigned a late Oligocene age (Rossbach \& Carter, 1991; Harris \& Laws 1997; Ward, 2002), a late Oligocene/early Miocene age (Ward, 1998), and an early Miocene age (Baum, Harris \& Zullo, 1978; Zullo, Willoughby \& Nystrom, 1982). Belgrade Quarry is in Onslow County, the location of the type section of the Belgrade Formation. The Belgrade Formation in Onslow County, including the designated type section (Baum, Harris \& Zullo, 1978), has been assigned to the early Miocene (Ward, Lawrence \& Blackwelder, 1978; Zullo, 1984).

Terrestrial vertebrates recovered from mine spoil piles are likely earliest Miocene (late late Arikareean, Ar4, 18-23 Ma, MN 2-3 equivalent) in age (MacFadden et al., 2017). The key specimen for this determination is the entelodont Daeodon. The holotype of Daeodon leidyanus is from the late late Arikareean Farmingdale Local Fauna. However, the range of Daeodon in North America is early Arikareean to early Hemingfordian (Lucas, Emry \& Foss, 1998). Pliocene mammal fossils are also present at Belgrade Quarry (B. MacFadden, 2019, pers. comm.). Therefore, it is necessary to compare NCSM 33670 with late Oligocene to Pleistocene taxa.

\section{Materials \& Methods}

Microtomography scans of the mandible were collected on a Zeiss Xradia 510 Versa nanoCT system, housed at the Analytical Instrumentation Facility at North Carolina State University. Measurements of fossil mammals at the American Museum of Natural History were made with digital calipers to the nearest $0.1 \mathrm{~mm}$. Subdivision of the Arikareean North American Land Mammal Age (Ar1-4) follows Albright et al. (2008).

\section{Results}

\section{Systematic Paleontology}

Order CARNIVORA Bowdich, 1821

Family AILURIDAE Gray, 1843

\section{Remarks}

Peer) reviewing PDF | (2020:03:46707:1:1:CHECK 7 May 2020) 
108

109

110

111

112

113

114

115

116

117

118

119

120

121

122

123

124

125

126

127

128

129

130

131

132

133

134

135

136

137

138

139

140

141

142

143

144

145

146

147

148

149

150

151

152

153

Baskin (1998b) had previously grouped the musteloids with an elongate $\mathrm{m} 2$ into a single family, the Procyonidae, with two subfamilies (Procyoninae and Ailurinae). His Ailurinae contained the tribes Simocyonini and Ailurini. In the present paper, we follow Morlo \& Peigné's (2010) classification of the Ailuridae. Ailuridae is the sister taxon to the Procyonidae and Mustelidae. Ailurus fulgens, the red panda, is the only extant ailurid. The late Oligocene to early Miocene Amphictis is the sole genus of the paraphyletic Amphictinae (Morlo \& Peigné, 2010) and is the stem sister taxon to the other two ailurid subfamilies, the Ailurinae and Simocyoninae.

Genus AMPHICTIS Pomel, 1853

Genotypic species: Amphictis antiqua (Blainville, 1842)

\section{Remark}

Morlo \& Peigné (2010) diagnosed the genus and characterized the eight species of Amphictis they considered valid: A. antiqua (Blainville, 1842); A. ambigua (Gervais, 1872); A. milloquensis (Helbing, 1928); A. borbonica Viret, 1929; A. schlosseri Heizmann and Morlo, 1994; $A$.

wintershofensis Roth in Heizmann and Morlo, 1994; A. prolongata Morlo, 1996; and A. cuspida Nagel, 2003. Baskin (2017) added a ninth species, A. timicua.

\section{?AMPHICTIS sp.}

Figs. 1-4; Table 1

Referred specimen. NCSM 33670, right mandible with p4, and alveoli for p1-p3, m1-m2; from Belgrade Quarry in Onslow County, North Carolina, USA.

Description: The mandible extends from posterior to the canine to the posterior alveolus of $\mathrm{m} 2$ (Fig. 1). It is somewhat shallower beneath the $\mathrm{p} 3$ (Table 1). Posterior from beneath the $\mathrm{p} 3$, the ventral border is gently convex posterior to beneath the $\mathrm{p} 3$. The mental foramen is below the anterior root of the $\mathrm{p} 3$, at approximately half the depth of the ramus. The coronoid process is missing. Length-wise cracks on the surface, porous bone, and polish on parts of the surface are indications of weathering and perhaps transport before burial.

The $\mathrm{p} 1$ is represented by a single, shallow alveolus. The roots are preserved in the $\mathrm{p} 2$ alveoli. The $\mathrm{p} 3$ alveoli contain the distal tips of the roots. The $\mathrm{p} 4$ is the only tooth in the mandible with crown elements preserved (Fig. 1). The relatively intact roots of $\mathrm{p} 2$ and $\mathrm{p} 4$ are preserved, as are the apical-most portions of both of the roots of $\mathrm{p} 3$ and much of the anterior root of $\mathrm{m} 1$ (Fig. 1B, $\mathrm{F})$. The main cusp of the $\mathrm{p} 4$ is broken anterior to the midline of the tooth. There is a distinct posterior accessory cusp on the external margin of the main cusp. The anterior cingulid is better developed antero-internally than antero-externally. The posterior cingulid is well developed.

The posterior root of the $\mathrm{m} 1$ is larger than the anterior root. The $\mathrm{m} 2$ is double rooted and situated on the slope of the ascending coronoid process. In the nano-CT volumetric reconstruction (Figs. $1 \mathrm{~B}, 1 \mathrm{~F})$, the posterior root appears smaller than the anterior root. However, the bone surface surrounding that alveolus is eroded. The reconstruction in Fig. 2 is based on illustrations of

Peer) reviewing PDF | (2020:03:46707:1:1:CHECK 7 May 2020) 
154

155

156

157

158

159

160

161

162

163

164

165

166

167

168

169

170

171

172

173

174

175

176

177

178

179

180

181

182

183

184

185

186

187

188

189

190

191

192

193

194

195

196

197

198

199

Amphictictis schlosseri (Heizman \& Morlo, 1994) and A. milloquensis (Cirot \& Wolsan, 1995), and casts of $A$. winterhofensis in the AMNH. As reconstructed, the two roots were nearly identical in depth, with the posterior alveolus extended upward and sloped toward the anterior margin of where the coronoid process would have been. Therefore, the $\mathrm{m} 2$ posterior root was a much more substantial structure that extended both distally and occlusally than what is preserved. There is a third small accessory rootlet between the anterior and posterior root.

\section{Discussion}

The presence of only a single, relatively non-diagnostic tooth, the $\mathrm{p} 4$, and the possibility that the jaw may not be late late Arikareean make a confident generic determination difficult. If an $\mathrm{m} 3$ were present, the root or its alveolus would have been evident in the microtomography scan (Fig. 1). The absence of an $\mathrm{m} 3$ indicates NCSM 33670 is a member of the Musteloidea - the Mephitidae, Ailuridae, Mustelidae, and Procyonidae (Wolsan, 1993; Wang, McKenna \& Dashzeveg, 2005). The highly sloping distal molar, transitioning to the coronoid process out of the strict occlusal plane, is another feature seen only in musteloids, and immediately identifies the jaw as neither a canid nor an amphicyonid. An elongate $\mathrm{m} 2$ and an elongate $\mathrm{m} 1$ talonid (as suggested by the larger posterior $\mathrm{m} 1$ alveolus) are characteristic of the Ailuridae and Procyonidae. NCSM 33670 was therefore compared with late Oligocene and early Miocene basal musteloids, mustelids, ailurids, and procyonids, as well as with middle Miocene and younger ailurids and other musteloids.

NCSM 33670 compares best with Amphictis, the earliest and most primitive member of the Ailuridae (Morlo \& Peigné, 2010). Amphictis is known from the late Oligocene (Arvernian, MP 28) to early Miocene (Orleanian, MN 3-4) of Europe (Heizmann \& Morlo, 1994, Cirot \& Wolsan, 1995; Morlo, 1996), the middle Miocene (late Orleanian, MN 5 or Astaracian, MN 6) of Turkey (Nagel, 2003), and the late early Miocene (early Hemingfordian, MN 4 equivalent) of North America (Tedford et al., 1987; Baskin, 2017). A possible earlier North American occurrence is AMNH 81029 (misnumbered AMNH 81040 in Baskin, 2017), a mandible from the late late Arikareean (AR4, MN 2-3 equivalent) of Nebraska identified as Bassariscus sp. (Cook \& Macdonald, 1962). Baskin (2004) considered AMNH 81029 Amphictis-like.

\section{The $\mathrm{m} 1$ length of NCSM 33670 is greater than that of Amphictis antiqua, A. borbonica. A.} wintershofensis, and A. timicua; similar to that of A. ambigua, A. milloquensis, and A. schlosseri; and less than that of A. cuspida (Heizman and Morlo, 1994; Cirot \& Wolsan, 1995; Nagel, 2003; Baskin, 2017). The teeth have similar length proportions such as the ratios of $\mathrm{p} 3, \mathrm{p} 4$, and $\mathrm{m} 2$ to $\mathrm{m} 1$ (Table 2, Fig. 3). The middle Miocene (MN 6) A. cuspida from Çandir, Turkey is the latest and largest species (Nagel, 2003). It is known from a lower jaw with p4-m2. Amphictis cuspida differs from other Amphictis, including NCSM 33670, in having a shorter $\mathrm{m} 2$ as compared to the $\mathrm{m} 1$ (Table 2, Fig. 3). The only other specimen in Fig. 3 with such a relatively short $\mathrm{m} 2$ is the holotype of Plesictis milloquensis from the Late Oligocene (MP 29) of La Milloque in southwestern France (Helbing, 1928) which Cirot \& Wolsan (1995) transferred to Amphictis. The additional specimen they identified as A. milloquensis (Cirot \& Wolsan, 1995: fig. 1) has the $\mathrm{m} 2: \mathrm{m} 1$ (Table 2) ratio the same as that of the early Miocene (MN 1-MN 2a) A. schlosseri from the Molasse basin and Mainz basin of southwestern Germany (Heizmann \& Morlo, 1994). Amphictis from the Hemingfordian of Florida and Nebraska (Baskin, 2017) is much smaller than 
200

201

202

203

204

205

206

207

208

209

210

211

212

213

214

215

216

217

218

219

220

221

222

223

224

225

226

227

228

229

230

231

232

233

234

235

236

237

238

239

240

241

242

243

244

245

NCSM 33670. The Bassariscus-like posterior ramus with alveoli for the posterior root of $\mathrm{m} 1$ and for two roots of an elongate $\mathrm{m} 2$ from the Hemingfordian Pollack Farm of Delaware is similar to these Florida and Nebraska Amphictis (Emry \& Eshelman, 1998; Baskin, 2003, 2017). NCSM 33670 is near the high end of the alveolar measurements of the species of Amphictis plotted in Fig. 3. Measurements of Amphictis ambigua from Quercy at Pech du Fraysse (MP 28) are most similar to those of NCSM 33670. The p4 of NCSM 33670 is similar to that of $A$. schlosseri (Heizmann \& Morlo, 1994: plate 2) in having well-developed anterior and posterior cingulids and an externally situated posterior accessory cusp. The posterior cingulid is wider in NCSM 33670 .

Alopecocyon from the middle Miocene of Europe (MN 6-MN 7/8) is closely related to Amphictis (Beaumont, 1976; Morlo \& Peigné, 2010). Beaumont (1976) noted that the lower dentition of Alopecocyon goeriachensis, the type species of the genus, was difficult to distinguish from that of Amphictis. Wolsan (1993) synonymized Alopecocyon with Amphictis. Plots of dental measurements (Figs. 3, 4) support Wolsan. However, Morlo \& Peigné (2010) noted that this had not been accepted by subsequent authors. Webb (1969), following a suggestion from D. E. Savage, synonymized Actiocyon (Stock, 1947) from the Clarendonian Nettle Spring Fauna of the Caliente Formation of California with Alopecocyon. Smith, Czaplewski \& Cifelli (2016) distinguished North American Actiocyon from Eurasian Alopecocyon by morphology of the cusps on m2. Actiocyon parverratis from the early Barstovian (MN 6 equivalent) of Nevada (Smith, Czaplewski \& Cifelli, 2016) and Actiocyon sp. from the late Clarendonian Ash Hollow Formation of Nebraska have an elongate $\mathrm{m} 2$ relative to $\mathrm{m} 1$, but only the Ash Hollow specimen has the m2 significantly more elongate than Amphictis (Table 2). More derived ailurids such as Pristinailurus from the late Miocene to early Pliocene Gray Fossil Site in Tennessee (Wallace \& Wang, 2004; Wallace, 2011) have a more complex p4 and an even more elongate $\mathrm{m} 2$. Tooth measurements (Table 2, Figs. 3, 4) indicate NCSM 33670 is more similar to the larger species of Amphictis than to Alopecocyon or other ailurids.

In North America, procyonids are known from the Hemingfordian of Florida, Nebraska, and Delaware. The procyonid from the early Hemingfordian Pollack Farm of Delaware (Emry \& Eshelman, 1998) is an M1 compared to Edaphocyon (Wilson, 1960). The only mandible attributed to this genus, the Hemingfordian ?E. palmeri (Baskin 2003), has an elongate $\mathrm{m} 2$ (Table 2), but differs from Amphictis and NCSSM 33670 in other dental proportions (Figs. 3, 4). The Hemingfordian Bassaricyonoides phyllismillerae (Baskin, 2003) has p4 much wider especially posteriorly and with a more prominent posterior accessory cusp on the postero-external margin. The Barstovian to Recent Bassariscus and the Barstovian Probassariscus are smaller than NCSM 33670 and have a more elongate $\mathrm{m} 2$. In the eastern U.S. procyonids occur in Clarendonian and younger sites of Florida. The only extant procyonid that may have been present in North Carolina in the Pliocene and Pleistocene is the raccoon Procyon. In Procyon the $\mathrm{m} 1$ and $\mathrm{m} 2$ are more or less equal in length (Wright \& Lundelius, 1963) and the p4 is noticeably wider posteriorly and has a more laterally situated posterior accessory cusp.

Plesictis is a small mustelid from the late Oligocene and early Miocene of Europe (Bonis, Gardin \& Blondel, 2019). Mustelavus priscus (Clark, 1936) is a musteloid from the late Eocene of western North America (Baskin, 1998a). Simpson (1946, p.13) considered Mustelavus a "probable synonym" of Plesictis. Because of similarities with the type of M. priscus, Macdonald

Peer) reviewing PDF | (2020:03:46707:1:1:CHECK 7 May 2020) 
246 (1970), following Simpson, identified an anterior mandible from the early Arikareean (Ar2) of

247 South Dakota as Plesictis sp. Tedford et al. (2004) noted this occurrence as an immigration event

248 for Plesictis. However, the generic identity of this South Dakota specimen has not been

249 demonstrated. Wang, McKenna \& Dashzeveg (2005) include the Chadronian to Orellan

250 Mustelavus priscus, Plesictis, and several other taxa as basal musteloids. The Orleanian

251 Plesictis? humilidens (Dehm, 1950) is from Wintershoff-West. Wolsan (1993) made it the type

252 species of Franconictis, which he classified as a mustelid that was the sister taxon of

253 Stromeriella. Both have a relatively long $\mathrm{m} 2$. Franconicits humilidens has similar dimensions

254 (Dehm, 1950: table 11) to those plotted in Figs. 3, 4 for Amphictis winterhofensis, other than a

255 somewhat shorter $\mathrm{m} 2$ length relative to $\mathrm{m} 1$ (Table 2).

256

257

258

259

260

261

262

263

264

265

266

267

268

269

270

271

272

273

274

275

276

277

278

279

280

281

282

283

284

285

286

287

288

289

290

The early Oligocene Peignictis pseudamphictis is an enigmatic musteloid known from a posterior ramus with $\mathrm{m} 1$ (Bonis, Gardin \& Blondel, 2019). The posterior alveolus of the $\mathrm{m} 2$ is smaller than the anterior one. It is much smaller than Amphictis (Table 2) and has an $\mathrm{m} 1$ morphology more like that of Mustelictis (Bonis, Gardin \& Blondel, 2019). Although the $\mathrm{m} 2$ is relatively long, the m2:m1 ratio is less than that of Amphictis or NCSM 33670.

The Oligobuninae are the sister group of the neomustelids (Baskin, 1998a, 2017; Valenciano et al. 2016). They, neomustelids, and procyonids are derived relative to ailurids in lacking an alisphenoid canal (Wang, McKenna \& Dashzeveg, 2005). Promartes, the earliest oligobunine, is known from the late early Arikareean (Ar3) to Hemingfordian. Its species are similar in size to NCSM 33670 (Fig. 4). They and the other oligobunines such as Floridictis, Zodiolestes, Oligobunis, Brachypsalis, and Parabrachypsalis (Baskin, 2017) differ from NCSM 33670 in having a relatively shorter $\mathrm{m} 2$ and a relatively longer $\mathrm{m} 1$ (Table 2, Fig. 4).

\section{Conclusions}

The late Oligocene and early Miocene are marked by the immigration of carnivorans from Eurasia to North America (Tedford et al., 2004: fig. 6.3). Among the musteloids, Mustelictis from the early Oligocene (MP 22, $32 \mathrm{Ma}$ ) of Quercy, France (Bonis, 1997) is one of the earliest stem mustelids (Wang, McKenna \& Dashzeveg, 2005). Corumictis wolsani, from the early Arikareean (Ar1, MP 24 equivalent, 30-28 Ma and Ar2) of Oregon, is the earliest stem mustelid in North America and is an immigrant taxon (Paterson et al., 2020). Promartes is the only oligobunine mustelid known from the Arikareean. Whether the Oligobuninae are autochthonous or allochthonous is unresolved. Crown clade mustelids and procyonids first appear in North America during the Hemingfordian. The procyonids are derived from a European early Miocene taxon such as Broiliana (Baskin, 1998b). Previously the earliest ailurids in North America were from the Hemingfordian of Florida and Nebraska (Baskin, 2017). NCSM 33670 is most similar to the late Oligocene Amphictis ambigua (MP 28) or the early Miocene A. schlosseri (MN 1-MN 2a). Based on marine invertebrates, as noted above, the Belgrade Formation has been considered late Oligocene (Chattian or Chickasawhayan) to early Miocene (Aquitanian) in age. MacFadden et al. (2017) propose a late late Arikareean (AR 4, MN 2-3 equivalent) age assignment for the mammals from the Belgrade Formation, In any case, an Arikareean (late Oligocene to early early Miocene) age assignment supports NCSM 33670 being an immigrant from Eurasia and the earliest record of the Ailuridae in North America. 
292 Institutional Abbreviations: AMNH, American Museum of Natural History, New York, New

293 York; F:AM, Frick Collection of fossil mammals in the AMNH; NCSM, North Carolina

294 Museum of Natural Sciences.

295

296

297

298

299

300

301

302

303

304

305

306

307

308

309

310

311

312

313

314

315

316

317

318

319

320

321

322

323

324

325

326

327

328

329

330

331

332

333

334

335

Anatomical Abbreviations: p, lower premolar; m, lower molar; L, length; W, width.

\section{Acknowledgements}

We thank Donald Clements for information on the stratigraphy of the region and providing assistance to John Dubois. Bruce MacFadden supplied information on the ages of the terrestrial vertebrates from the mine. We are grateful to Shruti Kolli and Abigail Malach for assistance with scanning of the specimen. Access to the AMNH collections was granted by Drs. Richard Tedford and Jin Meng, and assistance was provided by Judith Galkin. We thank M. Morlo, M. Wolsan, and an anonymous reviewer for the constructive comments that improved the manuscript.

\section{References}

Albright LB, Woodburne MO, Fremd TJ, Swisher CC, MacFadden BJ, Scott GR. 2008. Revised chronostratigraphy and biostratigraphy of the John Day Formation (Turtle Cove and Kimberly Members), Oregon, with implications for updated calibration of the Arikareean North American Land Mammal Age. Journal of Geology 116:211-237.

Baskin JA. 1998a. Mustelidae. In: Janis CM, Scott KM, Jacobs LL, eds., Evolution of Tertiary Mammals of North America. Cambridge, New York: Cambridge University Press. 152-173.

Baskin JA. 1998b. Procyonidae. In: Janis CM, Scott KM, Jacobs LL, eds., Evolution of Tertiary Mammals of North America. Cambridge, New York: Cambridge University Press. 144-151.

Baskin JA. 2003. New procyonines from the Hemingfordian and Barstovian of the Gulf Coast and Nevada, including the first fossil record of the Potosini. Bulletin of the American Museum of Natural History 279:125-146. https://doi.org/10.1206/0003-0090(2003)279<0125:C>2.0.CO;2

Baskin JA. 2004. Bassariscus and Probassariscus (Mammalia, Carnivora, Procyonidae) from the early Barstovian (middle Miocene). Journal of Vertebrate Paleontology 24:709-720. https://doi.org/10.1671/0272-4634(2004)024[0709:BAPMCP]2.0.CO;2

Baskin JA. 2017. Additional carnivorans from the early Hemingfordian Miller Local Fauna, Florida. Journal of Vertebrate Paleontology 37, https://doi.org/10.1080/02724634.2017.1293069.

Baum GR, Harris WBH, Zullo VA. 1978. Stratigraphic revision of the exposed middle Eocene to lower Miocene formations of North Carolina. Southeastern Geology 20:1-19. 
337 Beaumont G de. 1976. Remarques préliminaires sur le genre Amphictis Pomel (Carnivore).

338

339

340

341

342

343

344

345

346

347

348

349

350

351

352

353

354

355

356

357

358

359

360

361

362

363

364

365

366

367

368

369

370

371

372

373

374

375

376

377

378

379

380

381
Bulletin du Société Vaudoise des Sciences Naturelles 73:171-180.

Blainville, HMD de.1841. Ostéographie ou description iconographique comparée du squelette et du systéme dentaire des cinq classes d'animaux vertebras récents et fossils pour servir de base à la zoologie et à la géologie. Mammifères. Carnassiers: Vespertilio. Talpa. Sorex. Erinaceu.

Phoca. Ursus. Subursus. - Des petits-ours (G. Subursus). Paris: Arthus Bertrand.

Boessenecker RW, Ahmed E, Geisler JH. 2017. New records of the dolphin Albertocetus meffordorum (Odontoceti: Xenorophidae) from the lower Oligocene of South Carolina: Encephalization, sensory anatomy, postcranial morphology, and ontogeny of early odontocetes. PLoS ONE 12(11): e0186476. https://doi.org/10.1371/journal. pone.0186476

Bonis L de. 1997. Précisions sur l'age géologique et les relations phylétiques de Mustelictis olivieri nov. sp. (Carnivora, Mustelidae), carnassier de l'Oligocène inférieur (MP 22) des phosphorites du Quercy (France). Geobios 30, Supplement 1:55-60.

https://doi.org/10.1016/S0016-6995(97)80009-5.

Bonis L de, Gardin A, Blondel C. 2019. Carnivora from the early Oligocene of the 'Phosphorites du Quercy' in southwestern France, in Bonis L. de and Werdelin L. eds, Memorial to Stéphane Peigné: Carnivores (Hyaenodonta and Carnivora) of the Cenozoic. Geodiversitas 41:601-621. https://doi.org/10.5252/geodiversitas2019v41a15.

Bowdich TE. 1821. An Analysis of the Natural Classifications of Mammalia, for the use of Students and Travellers. Paris: J. Smith.

Cirot E, Wolsan M. 1995. Late Oligocene amphictids (Mammalia: Carnivora) from La Milloque, Aquitaine Basin, France. Géobios 28: 757-767. https://doi.org/10.1016/S0016-6995(95)80072-7.

Clark, J. 1936. Mustelavus priscus gen. et sp. nov. (Clark Ms.). In: Scott WB, Jepsen GL. The mammalian fauna of the White River Oligocene Part 1: Insectivora and Carnivora. Transactions of the American Philosophical Society 28:107-108.

Cook HC, Macdonald JR. 1962. New Carnivora from the Miocene and Pliocene of western Nebraska. Journal of Paleontology 36:560-567.

Dehm R. 1950. Die Raubtiere aus dem Mittel-Miocän (Burdigalium) von Wintershof-West bei Eichstätt in Bayern. Abhandlungen der Bayerischen Akademie der Wissenschaften 58:1-141.

Emry RJ, Eshelman RE. 1998. The early Hemingfordian (early Miocene) Pollack Farm Local Fauna: first Tertiary land mammals described from Delaware. In: Benson RN, ed., Geology and Paleontology of the Lower Miocene Pollack Farm Fossil Site, Delaware. Delaware Geological Survey Special Publication 21:153-173.

Eshelman RE, Whitmore FC, Jr. 2008. Early Pliocene (late Hemphillian) land mammals from the Lee Creek Mine, Aurora, North Carolina. In: Ray CE, Bohaska DJ, Koretsky IA, Ward LW,

Peer) reviewing PDF | (2020:03:46707:1:1:CHECK 7 May 2020) 
382 Barnes LG, eds., Geology and Paleontology of the Lee Creek Mine, North Carolina, IV. Virginia

383

384

385

386

387

388

389

390

391

392

393

394

395

396

397

398

399

400

401

402

403

404

405

406

407

408

409

410

411

412

413

414

415

416

417

418

419

420

421

422

423

424

425

426

427
Museum of Natural History Special Publication 14, Martinsville, Virginia. 17-38

Gallagher WB, Gilmore E, Parris DC, Grandstaff BS. 1995. Miocene land mammals from the Kirkwood Formation of New Jersey. Journal of Vertebrate Paleontology 15(sup3):30A-31A. https://doi.org/10.1080/02724634.1995.10011277.

Gervais, P. 1872. Mammifères dont les ossements accompagnent les dépôts de chaux phosphatée des départements du Tarn-et-Garonne et du Lot. Journal de Zoologie (Paris) 1:261-68.

Gray JE. 1843. List of the Specimens of Mammalia in the Collection of the British Museum. British Museum (Natural History) Publications, London.

Harris WB, Laws RA. 1997. Paleogene stratigraphy and sea-level history of the North Carolina Coastal Plain: global coastal onlap and tectonics. Sedimentary Geology 108:91-120.

Heizmann EPJ, Morlo M. 1994. Amphictis schlosseri n. sp. - eine neue Carnivoren-Art (Mammalia) aus dem Unter-Miozän von Südwestdeutschland. Stuttgarter Beiträge zur Naturkunde Serie B (Geologie und Paläontologie) 216:1-25.

Helbing H. 1928. Carnivoren des oberen Stampien. Abhandlungen der Schweizerischen Paläontologischen Gesellschaft 47(4):1-83.

Lucas, SG, Emry RJ, Foss SE. 1998. Taxonomy and distribution of Daeodon, an OligoceneMiocene entelodont (Mammalia: Artiodactyla) from North America. Proceedings of the Biological Society Of Washington 111:425-435.

Macdonald JR. 1970. Review of the Miocene Wounded Knee faunas of southwestern South Dakota. Bulletin of the Los Angeles County Museum of Natural History 8:1-82.

MacFadden BJ, Bohaska DJ, McCall LJ, Pirlo J, Niederkorn, J. 2017. The fossil project and citizen science: Early Miocene land mammals from Belgrade, North Carolina. Geological Society of America Abstracts with Programs 49.

https://gsa.confex.com/gsa/2017AM/webprogram/Paper299061.html.

McLeod SA, Barnes LG. 2008. A new genus and species of Eocene protocetidarchaeocete whale (Mammalia, Cetacea) from the Atlantic Coastal Plain. Natural History Museum of Los Angeles County Contributions in Science 41:73-98.

Morlo M. 1996. Carnivoren aus dem Unter-Miozän des Mainzer Beckens. Senckenbergiana lethaea 76:193-249. https://doi.org/10.1007/BF03042850.

Morlo M, Peigné S. 2010. Molecular and morphological evidence for Ailuridae and a review of its genera. In: Goswami A, Friscia A, eds., Carnivoran Evolution: New Views on Phylogeny, Form, and Function. Cambridge University Press, London, U.K. 92-140. 
428 Nagel D. 2003. Carnivora from the middle Miocene hominoid locality of Çandir (Turkey).

429 Courier Forschungsinstitut Senckenberg 240:113-131.

430

431

432

433

434

435

436

437

438

439

440

441

442

443

444

445

446

447

448

449

450

451

452

453

454

455

456

457

458

459

460

461

462

463

464

465

466

467

468

469

470

471

472
Paterson R, Samuels JX, Rybczynski N, Ryan MJ, Maddin HC. 2020. The earliest mustelid in North America. Zoological Journal of the Linnean Society. 188:1318-1339, https://doi.org/10.1093/zoolinnean/zlz091

Peigné S. 2012. Les Carnivora de Sansan. In: Peigné, S, Sen, S eds., Mammifères de Sansan. Mémoires du Muséum national d'Histoire naturelle, Paris 203 559-660

Pomel A. 1853. Catalogue des vertébrés fossils (suite). Annales scientifiques, littéraires et industrielles de l'Auvergne 26:81-229.

Rossbach TJ, Carter JG. 1991. Molluscan biostratigraphy of the lower River Bend formation at the Martin Marietta Quarry, New Bern, North Carolina. Journal of Paleontology 65:80-118. https://doi.org/10.1017/S0022336000020230.

Simpson GG. 1946. Palaeogale and allied early mustelids. American Museum Novitates 1320:1-14.

Smith K, Czaplewski, Cifelli RL. 2014. Middle Miocene carnivorans from the Monarch Mill Formation, Nevada. Acta Palaeontologica Polonica 61:231-253.

https://doi.org/10.4202/app.00111.2014

Snyder SW, Mauger LL, Akers WH. 1983. Planktonic foraminifera and biostratigraphy of the Yorktown Formation, Lee Creek Mine. In: Ray CE, ed., Geology and Paleontology of the Lee Creek Mine, North Carolina, I. Smithsonian Contributions to Paleobiology 53:455-481.

Stock C. 1947. A peculiar new carnivore from the Cuyama Miocene, California. Bulletin of the Southern California Academy of Science 46: 84-89.

Tedford RH, Hunter ME. 1984. Miocene marine--nonmarine correlations, Atlantic and Gulf Coastal Plains, North America. Palaeogeography, Palaeoclimatology, Palaeoecology 47: 129-151. https://doi.org/10.1016/0031-0182(84)90084-1

Tedford RH, Albright LB, Barnosky AD, Ferrusquia-Villafranca I, Hunt RM, Storer JE, Swisher CC, Voorhies MR, Webb SD, Whistler DP. 2004. Chapter 6. Mammalian Biochronology of the Arikareean through Hemphillian interval (late Oligocene through early Pliocene epochs) In: Woodburne MO, ed. Late Cretaceous and Cenozoic Mammals of North America. Biostratigraphy and Geochronology. New York: Columbia University Press. 169-231. https://doi.org/10.7312/wood13040-008

Tedford RH, Galusha T, Skinner MF, Taylor BE, Fields RW, Macdonald JR, Rensberger JM, Webb SD, Whistler DP. 1987. Faunal succession and biochronology of the Arikareean through Hemphillian interval (late Oligocene through earliest Pliocene epochs) in North America. In:

Peer) reviewing PDF | (2020:03:46707:1:1:CHECK 7 May 2020) 
473 Woodburne MO, ed. Cenozoic mammals of North America: geochronology and biostratigraphy.

474 Berkeley: University of California Press. 153-210.

475

476

477

478

479

480

481

482

483

484

485

486

487

488

489

490

491

492

493

494

495

496

497

498

499

500

501

502

503

504

505

506

507

508

509

510

511

512

513

Valenciano A, Baskin JA, Abella J, Pérez-Ramos A, Álvarez-Sierra MÁ, Morales J,

Hartstone-Rose A. 2016. Megalictis, the bone-crushing giant mustelid (Carnivora, Mustelidae, Oligobuninae) from the Lower Miocene of North America. PLOS ONE

https://doi.org/10.1371/journal.pone.0152430

Viret, J. 1929. Les faunes de mammifères de l'oligocène supérieur de la Limagne bourbonnaise. Annales de l'Université de Lyon 47:1-328.

Wallace SC. 2011. Advanced members of the Ailuridae ("Lesser" or Red Pandas - subfamily Ailurinae). In: Glatston A., ed., The Forgotten Panda. London: William Andrew Publishing. 43-60.

Wallace SC, Wang X. 2004. Two new carnivores from an unusual late Tertiary forest biota in eastern North America. Nature 431:2002-2005.

Wang X, McKenna MC, Dashzeveg D. 2005. Amphicticeps and Amphicynodon (Arctoidea, Carnivora) from Hsanda Gol Formation, central Mongolia and phylogeny of basal arctoids with comments on zoogeography. American Museum Novitates 3483:1-60.

Ward LW. 1998. Mollusks from the lower Miocene Pollack Farm site, Kent County, Delaware: A preliminary analysis. In: Benson RN, ed., Geology and Paleontology of the Lower Miocene Pollack Farm Fossil Site, Delaware. Delaware Geological Survey Special Publication 21:59-131.

Ward LW. 2002. Eocene and Oligocene Stratigraphy of Southeastern North Carolina. Virginia Museum of Natural History Guidebook 4:1-25.

Ward LW, Lawrence DR, Blackwelder BW. 1978. Stratigraphic revision of the middle Eocene, Oligocene, and Lower Miocene Atlantic Coastal Plain of North Carolina. United States Geological Survey Bulletin 1457-F: F1-F23.

Webb SD. 1969. The Pliocene Canidae of Florida. Bulletin of the Florida State Museum 14:273-308.

Wilson JA. 1960. Miocene carnivores, Texas coastal plain. Journal of Paleontology 34:983-1000.

514

515

516 Wright DB, Eshelman RE. 1987. Miocene Tayassuidae (Mammalia) from the Chesapeake Group 517 of the Mid-Atlantic coast and their bearing on marine-nonmarine correlation. Journal of

518 Paleontology 61:604-618. https://doi.org/10.1017/S0022336000028778 
519

520 Wright T, Lundelius E, Jr. 1963. Post-Pleistocene raccoons from central Texas and their

521

522

523

524

525

526

527

528

529

530

531

zoogeographic significance. Texas Memorial Museum, Pearce-Sellards Series 2:1-21.

Zullo VA. 1984. New genera and species of balanoid barnacles from the Oligocene and Miocene of North Carolina. Journal of Paleontology 58:1312-1338.

Zullo VA, Willoughby RH, Nystrom PG, Jr. 1982. A late Oligocene or early Miocene age for the Dry Branch Formation and Tobacco Road Sand in Aiken County, South Carolina. In: Nystrom, PG, Willoughby RH, eds., Geological investigations related to the stratigraphy in the kaolin mining district, Aiken County, South Carolina. Carolina Geological Society, Field Trip Guidebook for 1982. Columbia: South Carolina Geological Survey. 34-45. 
Figure 3. Scatter plots comparing tooth dimensions of selected early and middle Miocene ailurids

537 and procyonids. Symbols are as follows: $\star=\operatorname{NCSM~33670;\bullet =Amphictis~ambigua~} ;$ 538 Amphictis schlosseri $^{1} ; \mathbf{\Delta}=$ Amphictis milloquensis $^{2} ; \bullet=$ Amphictis winterhofensis $^{3} ; \mathbf{\Delta}=$

539 Amphictis cuspida ${ }^{4} ; \boldsymbol{\nabla}=$ Amphictis timicua $^{5} ; \boldsymbol{\nabla}=$ Amphictis cf. timicua $^{5} ; \mathbf{\square}=$ Actiocyon

540 parverratis $^{5} ; \mathbf{\square}=$ Alopecocyon $_{\text {goeriachensis }}^{6} ; \bullet=$ Bassaricyonoides phyllismillerae $^{7} ;$

541 ?Edaphocyon palmeri ${ }^{7}$. Sources of data: ${ }^{1}$ Heizman \& Morlo, 1994; ${ }^{2}$ Cirot \& Wolsan, 1995;

542 32Dehm, 1950; ${ }^{4}$ Nagel, 2003; ${ }^{5}$ Baskin, 2017; ${ }^{8}$ Smith et al., 2014; ${ }^{6}$ Peigné, 2012; ${ }^{7}$ Baskin. 2003.

543

544

545 
546 Figure 4. Scatter plots comparing tooth dimensions of selected Amphictis and early and middle

547 Miocene mustelids, and procyonids. Symbols are as follows: $\star=$ NCSM 33670; $\bullet=$ Amphictis

548 spp. $^{1} ; \bullet=$ Amphictis winterhofensis $^{2} ; \boldsymbol{\nabla}=$ Amphictis timicua $^{3} ; \boldsymbol{\nabla}=$ Amphictis $\mathrm{cf}$. timicua $^{3} ; \boldsymbol{\square}=$

549 Actiocyon parverratis ${ }^{4} ; \quad=$ Alopecocyon goeriachensis $5 ; \quad=$ Bassaricyonoides

550 phyllismillereae $; \quad=$ ?Edaphocyon palmeri ${ }^{6} ; \boldsymbol{\Delta}=$ Floridictis kerneri $^{3} ; \boldsymbol{\Delta}=$ Zodiolestes $^{3} ; \boldsymbol{\nabla}=$

551 Oligobunis ${ }^{3} ; \mathbf{\nabla}=$ Brachypsalis $^{3} ; \mathbf{4}=$ Promartes spp. ${ }^{3} ; \mathbf{4}=$ Parabrachypsalis janisae ${ }^{3}$. Sources

552 of data: ${ }^{1}$ Heizman \& Morlo (1994), Cirot \& Wolsan (1995); ${ }^{2}$ Dehm (1950); ${ }^{3}$ Baskin (2017);

$553 \quad{ }^{4}$ Smith et al.,(2014); ${ }^{5}$ Peigné (2012); ${ }^{6}$ Baskin (2003).

554

555 


\section{Figure 1}

Lateral $(A \& B)$, occlusal $(C \& D)$ and medial $(E \& F)$ views of volumetric reconstruction of NCSM 33670.

Mandibular bone (in gray) has been rendered semitransparent in B, D, and F to display root morphology. Preserved dental elements (root and crown fragments) are tan. Alveolar casts are rendered in red (canine), blue (p1), pink (p3), green (m1) and purple (m2). A-D, anterior is to the right; $E \& F$, anterior is to the left. Scale bar $=1 \mathrm{~cm}$.




Figure 2

Reconstruction of NCSM 33670 showing mandible with c1-m2.

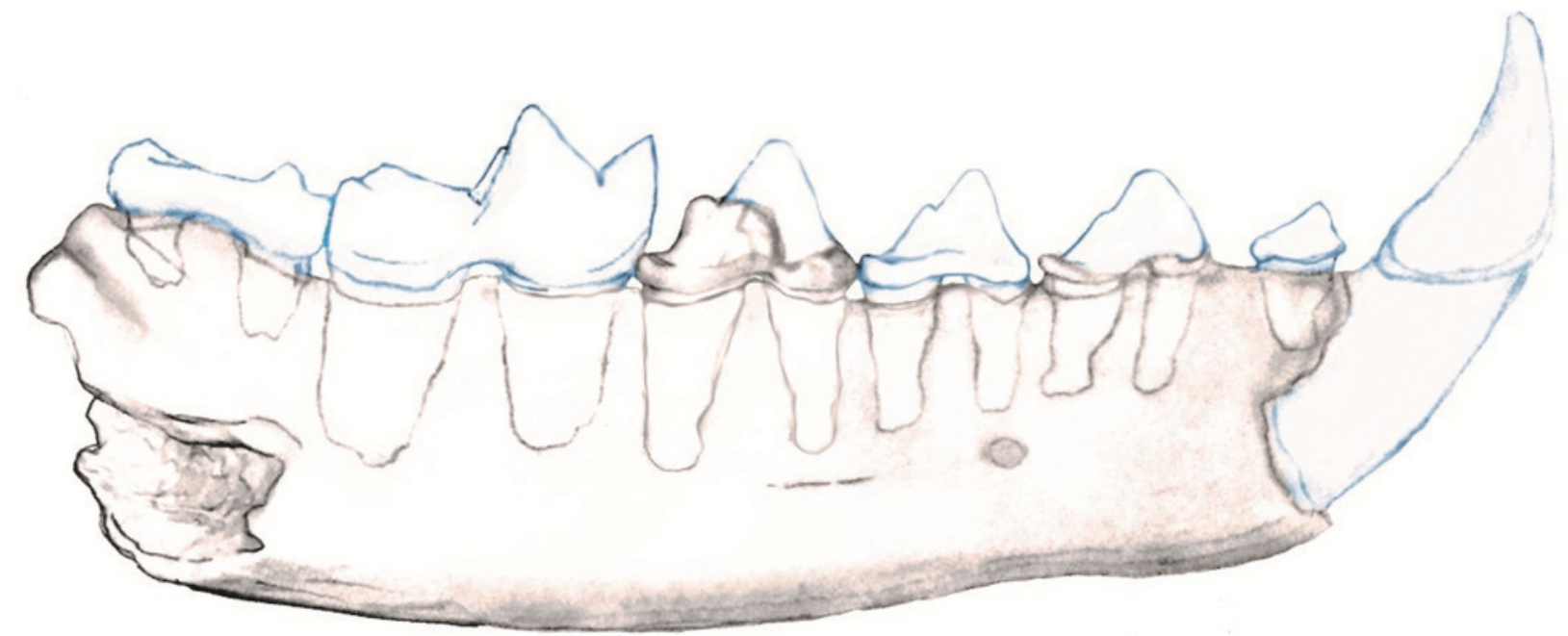




\section{Figure 3}

Scatter plots comparing tooth dimensions of selected early and middle Miocene ailurids and procyonids

Symbols are as follows: black star $\star=$ NCSM 33670; black $\bullet=$ Amphictis ambigua $^{1}$; black $=$ Amphictis schlosseri ${ }^{1}$; black $\mathbf{\Lambda}=$ Amphictis milloquensis ${ }^{2}$; red $\bullet=$ Amphictis winterhofensis ${ }^{3}$; red $\boldsymbol{\Lambda}=$ Amphictis cuspida ${ }^{4}$; black $\boldsymbol{\nabla}=$ Amphictis timicua ${ }^{5}$; red $\mathbf{\nabla}=$ Amphictis cf. timicua $^{5}$; red = Actiocyon parverratis ${ }^{5}$; black = Alopecocyon goeriachensis ${ }^{6}$; black $=$ Bassaricyonoides phyllismillerae ${ }^{7}$; red $\bullet=$ ?Edaphocyon palmeri ${ }^{7}$. Sources of data:

${ }^{1}$ Heizman \& Morlo, $1994 ;{ }^{2}$ Cirot \& Wolsan, $1995 ;{ }^{3}$ Dehm, 1950; ${ }^{4}$ Nagel, 2003; ${ }^{5}$ Baskin, 2017;

${ }^{8}$ Smith et al., 2014; ${ }^{6}$ Peigné, 2012; ${ }^{7}$ Baskin. 2003. 

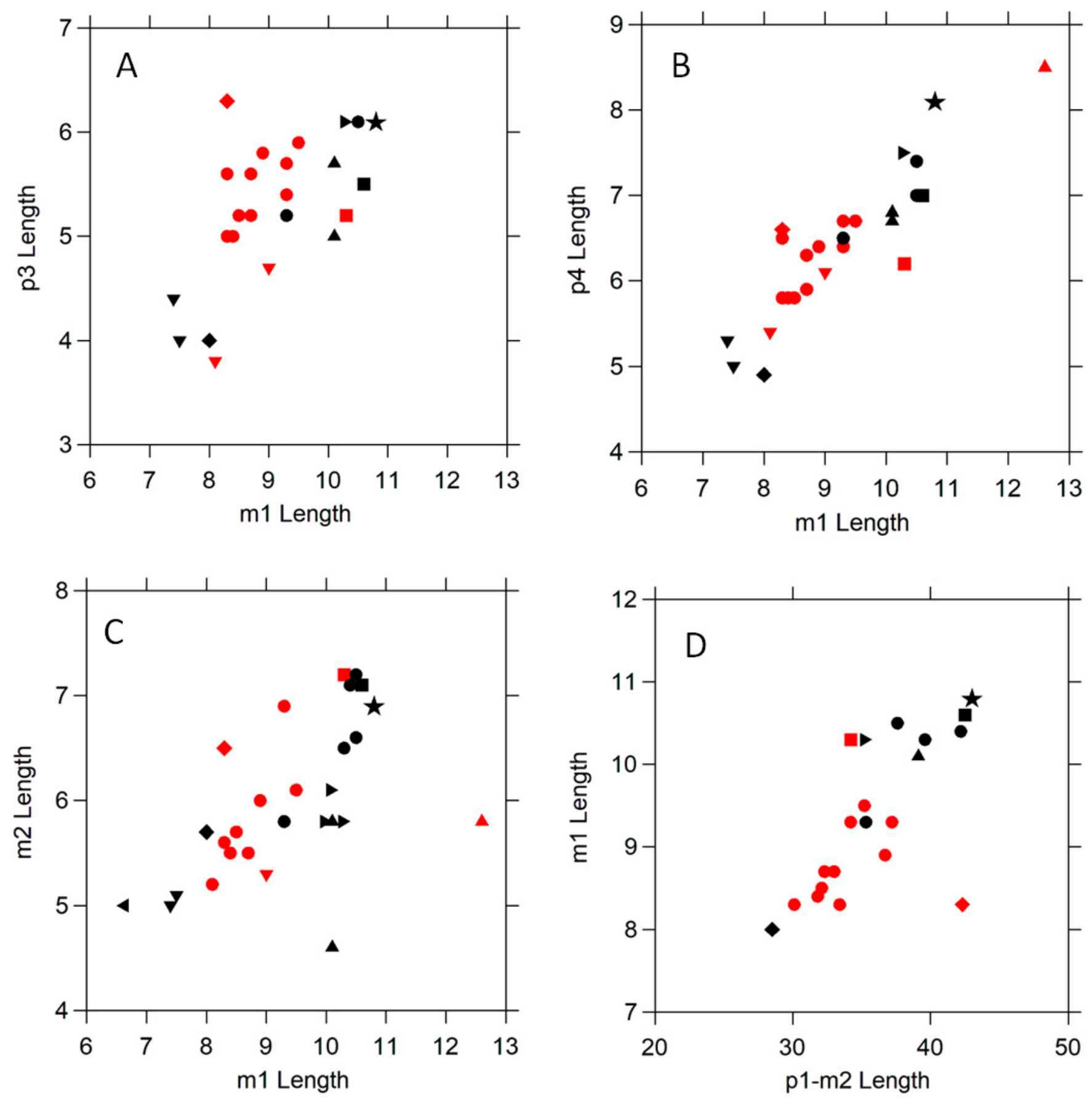


\section{Figure 4}

Scatter plots comparing tooth dimensions of selected Amphictis and early and middle Miocene mustelids, and procyonids.

Symbols are as follows: black star $\star=\operatorname{NCSM} 33670$; black $\bullet=$ Amphictis spp. ${ }^{1}$; red $\bullet=$ Amphictis winterhofensis ${ }^{2}$; black $\boldsymbol{\nabla}=$ Amphictis timicua $^{3}$; red $\mathbf{\nabla}=$ Amphictis cf. timicua $^{3}$; red $=$ Actiocyon parverratis ${ }^{4}$ black $=$ Alopecocyon goeriachensis ${ }^{5}$; black - Bassaricyonoides phyllismillereae ${ }^{6}$; red $\bullet=$ ?Edaphocyon palmeri ${ }^{6}$; black $\mathbf{\Lambda}=$ Floridictis kerneri ${ }^{3}$; red $\mathbf{}=$ Brachypsalis $^{3}$; black $\iota=$ Promartes spp. 3 ; red $\iota=$ Parabrachypsalis janisae ${ }^{3}$. Sources of data: ${ }^{1}$ Heizman \& Morlo (1994), Cirot \& Wolsan (1995); ${ }^{2}$ Dehm (1950); ${ }^{3}$ Baskin (2017); ${ }^{4}$ Smith et al.,(2014); ${ }^{5}$ Peigné (2012); ${ }^{6}$ Baskin (2003). 

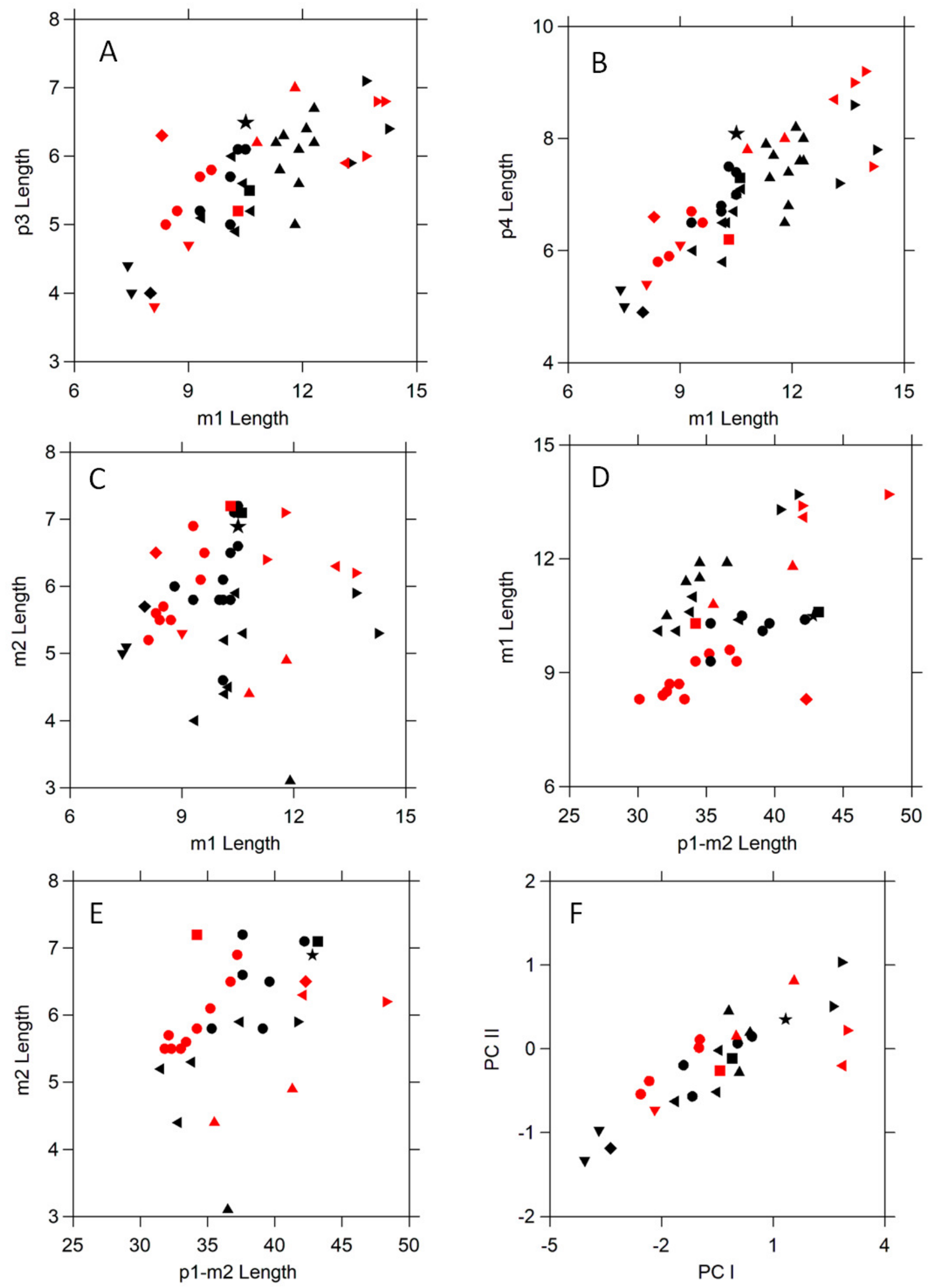

Peer) reviewing PDF | (2020:03:46707:1:1:CHECK 7 May 2020) 


\section{Table $\mathbf{1}$ (on next page)}

Measurements in mm on NCSM 33670.

$\mathrm{L}=$ length; $\mathrm{W}=$ width; Depth $\mathrm{p} 2$ and Depth $\mathrm{m} 1=$ depth of mandible below $\mathrm{p} 2$ and $\mathrm{m} 1$, respectively 
1

\begin{tabular}{|l|l|}
\hline $\mathrm{p} 2 \mathrm{~L}$ & 5.7 \\
\hline $\mathrm{p} 3 \mathrm{~L}$ & 6.1 \\
\hline $\mathrm{p} 41$ & 8.1 \\
\hline $\mathrm{p} 4 \mathrm{~W}$ & 4.0 \\
\hline $\mathrm{m} 1 \mathrm{~L}$ & 10.9 \\
\hline $\mathrm{m} 2 \mathrm{~L}$ & 6.9 \\
\hline $\mathrm{p} 2-\mathrm{m} 1 \mathrm{~L}$ & 31.6 \\
\hline p2-m2 L & 39.5 \\
\hline p1-m2 L & 42.8 \\
\hline Depth p2 & 10.75 \\
\hline Depth m1 & 12.5 \\
\hline
\end{tabular}

2

3 


\section{Table 2 (on next page)}

Measurements in mm of of taxa discussed in the text.

$\mathrm{n}=$ number of specimens of $\mathrm{p} 4, \mathrm{~m} 1, \mathrm{~m} 2$. Sources of data: ${ }^{1}$ Heizman $\&$ Morlo, $1994 ;{ }^{2} \mathrm{NMB}$ LM

554, Cirot \& Wolsan, 1995. ${ }^{3}$ FSP LM 1969 MC 2, Cirot \& Wolsan, 1995; ${ }^{4}$ Dehm, 1950; ${ }^{5}$ Morlo,

1996; ${ }^{6}$ Nagel, 2003; ${ }^{7}$ Baskin, 2017; ${ }^{8}$ Smith et al., 2014; ${ }^{9}$ Peigné, 2012; ${ }^{10}$ F:AM 25212, Ash

Hollow Formation, Nebraska; ${ }^{11}$ Bonis, Gardin \& Blondel, 2019. 


\begin{tabular}{|c|c|c|c|c|c|}
\hline & $\mathrm{n}$ & p4 L & $\mathrm{m} 1 \mathrm{~L}$ & $\mathrm{~m} 2 \mathrm{~L}$ & $\mathrm{~m} 2 \mathrm{~L} / \mathrm{m} 1 \mathrm{~L}$ \\
\hline NCSM 33670 & $1,1,1$ & 8.1 & 10.8 & 6.9 & 0.68 \\
\hline Amphictis antiqua $^{1}$ & $?, 1,1$ & & 9.3 & 5.9 & 0.63 \\
\hline Amphictis.ambigua ${ }^{1}$ & $3,5,5$ & $7.0 \pm 0.45$ & $10.2 \pm 0.51$ & $6.6 \pm 0.56$ & $0.65 \pm 0.031$ \\
\hline Amphictis.milloquensis ${ }^{2}$ & $1,1,1$ & 5.7 & 10.1 & 4.6 & 0.45 \\
\hline Amphictis milloquensis ${ }^{3}$ & $1,1,1$ & 5.0 & 10.1 & 5.8 & 0.57 \\
\hline Amphictis borbonica $^{5}$ & $1,1,1$ & 6.2 & 9.0 & 5.2 & 0.58 \\
\hline Amphictis borbonica $^{1}$ & $?, 1,1$ & & 9.4 & 5.2 & 0.55 \\
\hline Amphictis schlosseri $^{1}$ & $1,3,3$ & 7.5 & $10.1 \pm 0.15$ & $5.9 \pm 0.17$ & 0.58 \\
\hline Amphictis wintershofensis ${ }^{4}$ & $10,11,10$ & $6.3 \pm 0.37$ & $8.7 \pm 0.47$ & $5.8 \pm 0.47$ & $0.66 \pm 0.035$ \\
\hline Amphictis prolongata ${ }^{5}$ & $1,1,1$ & 6.5 & 8.8 & 6.0 & 0.68 \\
\hline Amphictis cuspida ${ }^{6}$ & $1,1,1$ & 8.5 & 12.6 & 5.8 & 0.46 \\
\hline Amphictis timicua ${ }^{7}$ & $2,2,2$ & $5.0,5.3$ & $7.5,74$ & $5.1,50$ & 0.68 \\
\hline Actiocyon parverratis ${ }^{8}$ & $1,1,1$ & 6.2 & 10.3 & 7.2 & 0.69 \\
\hline Alopecocyon goeriachensis 9 & $1,1,1$ & 7.0 & 10.6 & 7.1 & 0.66 \\
\hline Actiocyon sp. ${ }^{10}$ & $1,1,1$ & 7.0 & 15.4 & 11.8 & 0.76 \\
\hline Franconicits humilidens ${ }^{4}$ & $11,16,12$ & $6.5 \pm 0.32$ & $8.9 \pm 0.43$ & $4.7 \pm 0.31$ & $0.54 \pm 0.026$ \\
\hline Peignictis pseudamphictis ${ }^{11}$ & $?, 1,1$ & & 5.3 & 2.5 & 0.47 \\
\hline Floridictis kerneri $^{7}$ & $10,10,3$ & $7.5 \pm 0.53$ & $11.8 \pm 0.37$ & $2.8 \pm 0.23$ & 0.24 \\
\hline
\end{tabular}

